\title{
Penerapan Model Time Token Berbantuan Media Kartu Kuartet Untuk Meningkatkan Hasil Belajar Siswa Sekolah Dasar
}

\author{
Faiz Amalia, Mila Roysa, Erik Aditia Ismaya \\ PGSD FKIP, Universitas Muria Kudus, Jl. Lkr. Utara, Kayuapu \\ Kulon, Gondangmanis, Kec. Bae, Kabupaten Kudus, Jawa Tengah \\ Correspondence Email: 59327liapbg472@gmail.com
}

\begin{abstract}
This study aims to analyze the improvement of student learning outcomes in class IV SD N Tlogoharum o1 in the academic year 2019/2020. The research method used is classroom action research. The subjects of this study were students in grade IV SD N Tlogoharum o1, totaling 14 students. The research phase consists of planning, action, observation, reflection. Data collection methods for interviews, observations, tests and documentation. Data collection instruments used in the form of observation, tests and documentation. The data analysis technique used is descriptive qualitative and quantitative data analysis techniques. Before conducting class action research, namely student learning outcomes for Indonesian Language and social studies subjects IV grade is low. The pre-cycle conditions indicate that in Indonesian content there are 6 students who achieve mastery with an average grade of 70 while in social studies only 5 students who achieve mastery with an average grade of 67. The results showed that the learning outcomes of Indonesian students charge the cognitive domain in cycle I was 69 with $58 \%$ classical completeness and in cycle II the class average increased to 77 and classical completeness reached $78 \%$. Furthermore, the average class IPS load in cycle I 73 with a classical completeness of 65\%, then increased in the second cycle experienced a significant increase to 82 and classical completeness achieved, which is $85 \%$. While the indicators of success, which is $75 \%$. So, it can be concluded that the time token model can improve student learning outcomes in Class IV SDN Tlogoharum.
\end{abstract}

Keywords:

Time Token; Media Quartet Card; Elementary School

\begin{abstract}
Abstrak
Penelitian ini bertujuan untuk menganalisis peningkatan hasil belajar siswa kelas IV SDN Tlogoharum o1 tahun ajaran 2019/2020. Metode penelitian yang digunakan yakni penelitian tindakan kelas. Subjek penelitian ini, yaitu siswa kelas IV SDN Tlogoharum or yang berjumlah 14 siswa. Tahap penelitian terdiri dari perencanaan, tindakan, pengamatan, refleksi. Metode pengumpulan data wawancara, observasi, tes dan dokumentasi. Instrumen pengumpulan data yang digunakan berupa observasi, tes dan dokumentasi. Teknik analisis data yang digunakan adalah teknik analisis data deskriptif kualitatif dan kuantitatif. Sebelum dilakukan penelitian tindakan kelas, yaitu hasil belajar siswa muatan Bahasa Indonesia dan IPS kelas IV rendah. Kondisi awal pra siklus menunjukkan bahwa pada muatan Bahasa Indonesia terdapat 6 siswa yang mencapai ketuntasan dengan nilai rata-rata kelas 70 sedangkan pada muatan IPS hanya 5 siswa yang mencapai ketuntasan dengan nilai rata-rata kelas 67 . Hasil penelitian menunjukkan bahwa hasil belajar siswa muatan Bahasa Indonesia ranah kognitif pada siklus I adalah 69 dengan ketercapaian ketuntasan klasikal $58 \%$ dan pada siklus II rata-rata kelas mengalami peningkatan menjadi 77 dan ketercapaian ketuntasan klasikal, yaitu sebesar $78 \%$. Selanjutnya pada muatan IPS rata-rata kelas pada siklus I 73 dengan ketercapaian ketuntasan klasikal 65\%, kemudian meningkat pada siklus II mengalami kenaikan yang signifikan menjadi 82 dan ketercapaian ketuntasan klasikal, yaitu 85\%. Sedangkan indikator keberhasilannya, yaitu $75 \%$. Maka, dapat disimpulkan bahwa model time token dapat meningkatkan hasil belajar siswa di Kelas IV SDN Tlogoharum.
\end{abstract}

Kata Kunci:

Time Token, Media Kartu Kuartet, Sekolah Dasar 


\section{Pendahuluan}

Sjukur (2012:372) menyebut hasil belajar adalah kemampuan yang diperoleh individu setelah proses belajar berlangsung, yang dapat memberikan perubahan tingkah laku baik pengetahuan, pemahaman, sikap dan keterampilan siswa sehingga menjadi lebih baik dari sebelumnya. Rendahnya hasil belajar siswa kelas IV SDN Tlogoharum o1 perlu mendapat perbaikan oleh karena itu peneliti memilih model time token berbantuan media kartu kuartet. Model time token dipilih karena siswa diminta untuk aktif mengungkapkan pendapatnya tanpa merasa malu dan takut serta bertujuan untuk mengembangkan keterampilan sosial siswa sehingga tepat digunakan dalam proses pembelajaran. Pemilihan kartu kuartet didukung oleh riset Nisa (2017) yang menunjukkan bahwa terjadi peningkatan hasil belajar kimia siswa kelas X.1 dengan persentase ketuntasan belajar pada siklus I sebesar 75,68\% dan meningkat pada siklus II menjadi 82,86\%. Peningkatan ini menunjukkan penerapan model pembelajaran kooperatif tipe time token dapat meningkatkan hasil belajar siswa.

Penggunaan model pembelajaran time token yang tepat untuk meningkatkan hasil belajar siswa yang peneliti gunakan dibantu dengan menggunakan media kartu kuartet. Kartu kuartet adalah suatu permainan kartu yang terdiri dari tulisan dan gambar dengan tema yang telah ditentukan serta dimainkan oleh 2 sampai 4 pemain. Penggunaan kartu kuartet didukung oleh riset Setiyorini (2013) menemukan bahwa penggunaan media kartu kuartet dapat meningkatkan hasil belajar siswa di sekolah dasar. Hal ini dapat dilihat dengan peningkatan hasil belajar siswa pada siklus I memperoleh rata-rata $66,67 \%$, sedangkan siklus II kembali naik menjadi $72,22 \%$ dan siklus III meningkat 91,66\%. Peningkatkan ini menunjukkan bahwa penggunaan media kartu kuartet dapat meningkatkan hasil belajar siswa, bahkan melebihi target yang telah ditentukan, yaitu 75\%.

Adapun langkah-langkah penggunaan kartu kuartet menurut Rostina (2017: 234) antara lain: a) siswa dibagi ke dalam kelompok yang setiap kelompok terdiri 4 orang, b) setiap pemain dalam diberi satu set kartu kuartet, c) setiap pemain dalam satu kelompok berusaha mengumpulkan dan mencari pasangan dari tema kartu yang dimilikinya yang belum lengkap. Pemain boleh bertanya kepada lawan yang duduk di depan atau samping kanan dan kirinya, d) apabila nama kartu yang dimaksud tepat maka lawan harus menyerahkannya kepada si peminta karu, tetapi apabila salah permainan dilanjutkan pada penanya berikutnya, e) apabila sudah terkumpul 4 kartu berpasangan maka kartu tersebut ditumpuk berjejer di depan pemain, f) setelah semua kartu habis dan terkumpul maka diadakan perhitungan akhir siapa yang terbanyak berk dan yang sedikit, g) permainan akan lebih menarik apabila pemenang diberi penghargaan dan yang kalah diberi hukuman.

Kondisi awal pada saat observasi pada tanggal 28 Oktober 2019 di kelas IV SDN Tlogoharum o1 masih ditemukan berbagai permasalahan diantaranya pembelajaran di kelas tidak berjalan secara kondusif, siswa membuat kegaduhan di kelas. Pada saat guru menerangkan materi pembelajaran, siswa tidak mendengarkan malah melamun dan mengantuk. Permasalahan lain yang peneliti temukan, yaitu guru tidak menerapkan model dan media pembelajaran yang menyenangkan sehingga menyebabkan antusias belajar siswa rendah. Selama pembelajaran guru hanya menggunakan metode ceramah, hal tersebut mengakibatkan siswa cenderung pasif tidak bersemangat dalam mengikuti kegiatan belajar mengajar. Berdasarkan data hasil Penilaian Tengah Semester (PTS) siswa kelas IV SDN Tlogoharum o1 ditemukan bahwa dari 14 siswa, hanya 5 siswa atau 36\% yang tuntas dan siswa yang tidak tuntas 
sebanyak 9 siswa atau $64 \%$.

Berdasarkan latar belakang di atas maka, untuk mengatasi hasil belajar peneliti melakukan riset dengan rumusan masalah sebagai berikut: Bagaimanakah peningkatan hasil belajar dengan menerapkan model pembelajaran time token berbatuan media kartu kuartet pada tema 7 indahnya keragaman di negeriku Kelas IV SD N Tlogoharum o1? Dengan tujuan untuk menganalisis peningkatan hasil belajar siswa kelas IV SD N Tlogoharum or tahun ajaran 2019/2020.

\section{Metode}

Jenis penelitian yang digunakan adalah penelitian tindakan kelas. Penelitian tindakan kelas ini dilaksanakan di SDN Tlogoharum o1 Kecamatan Wedarijaksa Kabupaten Pati. Subjek dalam penelitian ini, yaitu siswa kelas IV SDN Tlogoharum o1 semester ganjil tahun ajaran 2019/2020. Jumlah siswa yang terdapat pada kelas IV, yaitu 14 siswa terdiri dari 4 laki-laki dan 10 perempuan. Penelitian tindakan kelas ini menggunakan model Kemmis dan Mc Taggart. Desain penelitian tindakan kelas yang digunakan dalam penelitian ini, terdapat empat tahapan, yaitu (1) perencanaan, (2) pelaksanaan, (3) pengamatan, (4) refleksi. Teknik pengumpulan data yang akan digunakan dalam penelitian ini, yaitu wawancara, observasi, tes dan dokumentasi.

Teknik analisis data yang digunakan dalam penelitian ini menggunakan teknik analisis data kuantitatif dan kualitatif. Data kuantitatif diperoleh dari hasil belajar siswa ranah pengetahuan melalui tes evaluasi yang berjumlah 10 soal. Sedangkan data kualitatif ini diperoleh dari hasil pengamatan yang dilakukan selama proses pembelajaran, yaitu hasil belajar ranah pengetahuan dengan penerapan media kartu kuartet. Ketuntasan nilai yang diperoleh siswa kemudian dihitung menggunakan rumus sebagai berikut:

Nilai $=$ QUOTE $\times 100$

Sumber: Panduan Penilaian Kurikulum 2013 Indikator keberhasilan yang diharapkan untuk hasil belajar siswa ranah pengetahuan memperoleh minimal ketuntasan $\geq 75$ dengan persentase $\geq 75 \%$.

\section{Hasil dan Pembahasan}

Penelitian tindakan kelas dilakukan dengan persetujuan guru kelas IV, dengan kesepakatan bahwa siklus I dilaksanakan pada tanggal 19-20 Februari 2020. Dimana pertemuan 1 dilaksanakan pada tanggal 19 Februari 2020 dan pertemuan 2 dilaksanakan pada tanggal 20 Februari 2020. Siklus II dilaksanakan pada tanggal 24 dan 25 Februari 2020, dimana pertemuan 1 dilaksanakan pada tanggal 24 Februari 2020 dan pertemuan 2 dilaksanakan pada tanggal 25 Februari 2020.

Berdasarkan analisis yang telah dilakukan, hasil data yang diperoleh pada setiap siklusnya sebagai berikut.

\subsection{Hasil Belajar Siswa Ranah Pengetahuan}

Hasil belajar siswa pada siklus I diperoleh dari kegiatan tes evaluasi akhir siklus dengan menerapkan model time token berbantuan media kartu kuartet. Siswa yang mengikuti tes berjumlah 14 siswa. Peningkatan hasil belajar siswa berdasarkan siklus I dengan siklus II diperoleh data melalui tabel 1 sebagai berikut.

Tabel 1. Peningkatan Hasil Belajar Ranah Pengetahuan Siklus I-II

\begin{tabular}{ccc}
\hline Pencapaian & Siklus I & Siklus II \\
\hline Nilai Terendah & 60 & 65 \\
\hline
\end{tabular}




\begin{tabular}{ccc}
\hline Nilai Tertinggi & 85 & 90 \\
\hline Rata-rata Kelas & 73 & 82 \\
\hline Ketuntasan Klasikal & $65 \%$ & $85 \%$ \\
\hline
\end{tabular}

Murtono (2017) berpendapat bahwa terdapat enam indikator hasil belajar ranah pengetahuan, yaitu pengetahuan atau ingatan $\left(\mathrm{C}_{1}\right)$, pemahaman $\left(\mathrm{C}_{2}\right)$, aplikasi atau penerapan $\left(C_{3}\right)$, analisis $\left(C_{4}\right)$, evaluasi $\left(C_{5}\right)$ dan mencipta (C6). Berdasarkan tabel 2 tersebut, dapat diketahui bahwa adanya peningkatan hasil belajar yang diperoleh pada pelaksanaan siklus I dan siklus II. Nilai terendah pada siklus II, yaitu 65, nilai tertinggi 90, rata-rata kelas 82 beserta ketuntasan klasikal $85 \%$. Maka dari hasil penelitian tersebut maka dapat disimpulkan bahwa penerapan media kartu kuartet dapat meningkatkan hasil belajar IPS pada siswa kelas IV SDN Tlogoharum or dikatakan berhasil, karena hasil belajar telah mencapai indikator penelitian yang telah ditetapkan, yaitu $\geq 75$.

Hasil penelitian pada siklus I diketahui bahwa siswa masih belum faham memainkan kartu kuartet dikarenakan pada saat guru menjelaskan media tersebut terdapat siswa yang tidak mendengarkan, siswa tidak mau berkelompok. Untuk mengtasi permasalahan tersebut, guru memilih pembelajaran dengan model time token berbantuan media kartu kuartet. Dengan menerapkan model dan media pembelajaran diharapkan kepada seluruh siswa supaya aktif, guru juga mendorong siswa untuk memberanikan diri dalam berbicara menyampaikan pendapat.

Setelah dilakukan perbaikan pada siklus II terlihat siswa sudah lancar saat memainkan kartu kuartet, siswa sudah mau mendengarkan penjelasan guru, siswa sudah mau bergabung dengan anggota kelompok dan siswa mulai berani mengutarakan pendapatnya. Penerapan model pembelajarn time token menunjukkan peningkatan pada siklus I dan siklus II, karena model time token membuat siswa dibentuk ke dalam kelompok belajar yang dalam pembelajaran ini mengajarkan keterampilan sosial untuk menghindari siswa mendominasi pembicaraan atau menghindarkan siswa diam sama sekali dalam berdiskusi (Shoimin, 2014: 216).

Permasalahan lain yang peneliti temukan, yaitu dalam melaksanakan pembelajaran siswa belum bisa dikondisikan sehingga siswa perlu diberikan alat atau media untuk menarik perhatian siswa. Oleh karena itu untuk mewujudkan situasi pembelajaran yang menyenangkan dan pembelajaran yag efektif guru dapat menggunakan metode permainan. Minat belajar siswa semakin terlihat dengan digunakannya metode permainan kartu kuartet sebagai media pembelajaran.

\subsection{Hasil Belajar Siswa Ranah Keterampilan}

Rekapitulasi hasil belajar siswa ranah keterampilan dengan penerapan model time token berbantuan media kartu kuartet di kelas IV SDN Tlogoharum o1 disajikan dalam tabel 2 berikut.

Tabel 2. Peningkatan Hasil Belajar Siswa Ranah Keterampilan Siklus I-II

\begin{tabular}{ccc}
\hline Pelaksanaan & $\begin{array}{c}\text { Rata-rata } \\
\text { Persentase }\end{array}$ & Kualifikasi \\
\hline Siklus I & $54 \%$ & Cukup \\
\hline
\end{tabular}


647 | Naturalistic: Jurnal Kajian Penelitian dan Pendidikan dan Pembelajaran, Volume 5 Issue 1,

\begin{tabular}{lll}
\hline Siklus II & $85 \%$ & Sangat baik \\
\hline
\end{tabular}

Pada hasil belajar siswa ranah keterampilan, pedoman yang peneliti gunakan mencakup 5 kemampuan. Menurut Rosa (2015) penilaian hasil belajar psikomotor mencakup: kemampuan menggunakan alat dan siap kerja, kemampuan menganalisis suatu pekerjaan dan menyusun urut-urutan pengerjaan, kecepatan mengerjakan tugas, kemampuan membaca gambar atau simbol, keserasian bentuk dengan yang diharapkan atau ukuran yang telah ditentukan.

Berdasarkan tabel 2 menunjukkan perkembangan keterampilan siswa dalam pembelajaran menggunakan model time token mengalami peningkatan pada setiap siklusnya. Pada siklus I keterampilan siswa mencapai rata-rata persentase 54\% dengan kualifikasi cukup dan meningkat 31\% pada siklus II menjadi $85 \%$ dengan kualifikasi sangat baik. Temuan penelitian menunjukkan bahwa siswa yang cenderung pasif dalam pembelajaran menjadi terbiasa aktif dengan menggunakan kupon berbicara untuk mengungkapkan pendapat. Pemberian kupon berbicara pada proses pembelajaran mampu melatih siswa untuk meningkatkan pemahaman siswa tentang materi belajar.

Hal ini dikuatkan dengan hasil penelitian Tirabidah (2016) yang mengemukakan bahwa adanya pemberian kesempatan yang sama kepada siswa untuk bertanya dan menjawab menggunakan kupon berbicara selama proses pembelajaran serta motivasi siswa dalam berbicara mengalami peningkatan yang sangat baik. Dalam situasi ini, guru dapat membantu siswa untuk meningkatkan pengetahuan siswa terhadap materi yang dipelajari dengan menggunakan kupon berbicara.

Kemudian dalam menulis informasi baru dan ide pokok siswa masih kesulitan untuk menyampaikannya. Banyak siswa yang belum mampu menulis dengan bahasa yang runtut dan kosakata baku. Kanzunudin (2016) berpendapat bahwa diperlukan adanya kesatuan kepaduan, keruntutan dan ketuntasan dalam penulisan. Namun siswa menulis kalimat dengan menggunakan bahasa yang tidak dapat dipahami dan juga siswa banyak yang belum tuntas menyelesaikan kalimatnya. Sehingga perlu adanya latihan-latihan yang diberikan oleh guru untuk menstimulasi siswa agar mampu menulis dengan baik.

Penelitian yang dilakukan memiliki persamaan dan perbedaan dengan riset Mirnawati, Kanzunnudin dan Oktavianti (2015), penelitian Habiba (2017), riset Putri dan Suprayitno (2018), penelitian Suryanti, Suroso dan Yustinus (2018), riset Pamungkas, Kristin dan Anugraheni (2018), riset Annisa, Heryanto, Rusilowati dan Subali (2018), penelitian Diantoro, Ismaya dan Widianto (2020), riset Sulistyani (2020). Persamaan yang dimaksud, yaitu dipilihnya model pembelajaran time token, media kartu kuartet, metode penelitian tindakan kelas, peningkatan hasil belajar dan ranah pengetahuan serta keterampilan. Adapun perbedaannya, yaitu pada fokus pembelajaran dan hasil data penelitian yang diperoleh.

Penelitian habiba (2017) menunjukkan bahwa terjadi peningkatan hasil belajar pada siklus I dari 48,9 dan meningkat pada siklus II menjadi 76,8. Sementara itu penelitian Putri (2018) menunjukkan bahwa terjadi peningkatan hasil belajar setiap siklusnya. Lebih lanjut riset Sulistyani (2020) menunjukkan bahwa terjadi peningkatan keterampilan menulis dari siklus I sebesar 68,27 dan meningkat pada siklus II menjadi 75,76 .

\section{Simpulan}

Berdasarkan penelitian tindakan kelas yang dilakukan di kelas IV SDN Tlogoharum o1 dapat disimpulkan bahwa penerapan model time token berbantuan media kartu kuartet dapat meningkatkan hasil belajar 
siswa ranah pengetahuan dan keterampilan.

Hasil belajar siswa ranah pengetahuan mengalami peningkatan, pada muatan Bahasa Indonesia pada siklus I dengan persentase klasikal 58\%, siklus II memperoleh persentase klasikal $78 \%$. Selanjutnya, untuk muatan IPS siklus I mendapat persentase klasikal 35\%, dan siklus II mengalami peningkatan menjadi $85 \%$.

Hasil belajar siswa ranah keterampilan juga mengalamu peningkatan, pada siklus I sebesar 54\% katergori cukup, kemudian pada siklus II mengalami kenaikan yang signifikan menjadi $85 \%$ dengan kategori sangat baik.

\section{Daftar Pustaka}

Annisa, Rizki. Dkk. 2018. Peningkatan Daya Ingat dan Hasil Belajar Siswa Dengan Mind Mapping Method Pada Materi Listrik Dinamis. Jurnal Pendidikan (Teori dan Praktik). Vol. 3, No. 1, 19.

Diantoro, Cahyo Tris., Ismaya, Erik Aditia., dan Widianto, Eko. 2020. Peningkatan Hasil Belajar Siswa Melalui Model Quantum Teaching Berbantuan Media Aplikasi Edmodo Pada Siswa Sekolah Dasar. Wasis : Jurnal Ilmiah Kependidikan. Vol. 1, No. 1, 1.

Habiba, Riefka Iesna. 2017. Peningkatan Hasil Belajar Dengan Media Kartu Kuartet Dalam Keterampilan Menyusun Portofolio. Ilmu Pendidikan. Vol. 2, No. 1, 90.

Kanzunnudin. 2016. Bahasa Indonesia Untuk Perguruan Tinggi. Yogyakarta: Magnum Pustaka Utama.

Mirnawati, Kanzunnudin, Moh., dan Oktavianti, Ika. 2015. Peningkatan Hasil Belajar IPS Melalui Model Contextual Teaching And Learning Pada Siswa Kelas IV SD 2 Bacin Kudus Tahun 2013/2014. Refleksi Edukatika: Jurnal Ilmiah Kependidikan, 5 (1).

Murtono. 2017. Merencanakan dan Mengelola Model-Model Pembelajaran

\section{Inovatif. Ponorogo: WADE GROUP.}

Nisa, Khoirotun. 2017. Peningkatan Partisipasi Aktif dan Hasil Belajar Menggunakan Model Cooperative Learning Time Token Pada Materi Ikatan Kimia Siswa Kelas X.1 SMA Negeri 8 Banjarmasin Tahun Pelajaran 2015/2016. Jurnal PTK Pendidikan. Vol. 3, No. 2, 19.

Pamungkas, Andika Dinar., Kristin, Firosalia., dan Anugraheni Indri. 2018. Meningkatkan Keaktifan dan Hasil Belajar Siswa Melalui Model Pembelajaran Problem Based Learning $(P B L)$ pada Siswa Kelas 4 SD. Naturalistic: Jurnal Kajian Penelitian Pendidikan dan Pembelajaran. Vol. 3, No. $1,287$.

Putri, Nurul Madani dan Suprayitno. 2018. Penerapan Model Pembelajaran Time Token untuk Meningkatkan Hasil Belajar IPS Siswa Kelas 4 Tema Indahnya Keragaman di Negeriku SDN 2 Slempit Kedamean Gresik. JPGSD. Vol. o6, No. 11, 2022.

Rosa. Octavia Friska. 2015. Analisis Kemampuan Siswa Kelas X pada Ranah Kognitif, Afektif dan Psikomotorik. Jurnal Fisika dan Pendidikan Fisika. Vol. 1, No. 2, 25.

Rostina. 2017. Penggunaan Media

Permainan Kartu Kuartet dalam Meningkatkan Hasil Belajar Matematika Pada Materi Faktorisasi Suku Aljabar Siswa Kelas VII.1 MTSN Matangglumpangdua Kabupaten Bireuen. Jurnal Media Inovasi Edukasi. Vol. 03, No. 09, 234.

Setiyorini, Indah dan Husni Abdullah. 2013. Penggunaan Media Permainan Kartu Kuartet Pada Mata Pelajaran IPS untuk Peningkatan Hasil Belajar Siswa di Sekolah Dasar. JPGSD. Vol. o1, No. 02, o-216.

Shoimin, Aris. 2014. 68 Model pembelajaran Inovatif dalam Kurikulum 2013. Yogyakarta: AR-RUZZ MEDIA. 
Sjukur, B. Sulihin. 2012. Pengaruh Blended Learning Terhadap Motivasi Belajar dan Hasil Belajar Siswa Tingkat SMK. Jurnal Pendidikan Vokasi. Vol. 2, No. 3, 372.

Sulistyani. 2020. Upaya Meningkatkan Keterampilan Menulis Huruf Jawa Melalui Diskusi Kelompok Berbantu Kartu Huruf Pada Peserta Didik Kelas VI SD 1 Prampatan Kidul Kudus. Refleksi Edukatika : Jurnal Ilmiah Kependidikan. Vol. 10, No. 2 (1).

Suryanti, Dewi Putri., Suroso., dan Yustinus. 2018. Penerapan Model Pembelajaran Kooperatif Tipe Make A Match Berbantuan Media Puzzle Untuk Meningkatkan Keaktifan dan Hasil Belajar IPS Kelas 4 SD Negeri Dukuh O2 Salatiga Tahun Pelajaran 2017/2018. Naturalistic: Jurnal Kajian Penelitian Pendidikan dan Pembelajaran. Vol. 2, No. 2, 216. 